возрасте. Отсутствие побочных эффектов, доступность применения фототерапии позволяют рекомендовать использование этого метода для коррекции и профилактики психовегетативных расстройств у школьников в амбулаторных условиях в осенне-зимний период. Время сеанса, достаточное для достижения терапевтического эффекта фототерапии, у детей составляет 30 минут (курс лечения - 10 дней).

\section{ЛИТЕРАТУРА}

1. Aнmponoв Ю.Ф. Психосоматические расстройства и патологические привычные действия у детей и подростков.-М., 1999.

2. Божко Г.Х., Царицинский В.Н., Кулабуков В.М., Таранская А.Д. //Журн. невропатол. и психиатр.1995. -№ 4. - С. $51-54$.

3. Божко Г.Х., Царицинский В.Н, Стреляная Е.И., Таранская А.Д. //Журн. невропатол. и психиатр.1996. - № 1.-С.58-60.

4. Веснина В.А., Пикулин С.Д. //Труды 2-го ММИ им. Н.И.Пирогова.-М., 1974.-.С.225-228.

5. Кваскова И.В., Шварков С.Б. //Журн. невропатол. и психиатр. -1999. -№ 1.-С.15-17.

6. Кушнир C.M. Berero-сосудистая дистония у детей: Автореф. дис. ... д-ра мед. наук.-1995.
7. Левин Я.М., Артеменко А.Р. Фототерапия.M., 1996.

8. Левин Я.М., Артеменко А.Р. //Журн. невропатол. и психиатр. - 1996. - № 3.-С.107-117.

9. Макаренко Ю.А. Пути изучения эмоций у детей.-М., 1976.

10. Малиновская Н.К. //Клин. медицина.-1998.№ 10.-C.15-21.

11. Малышева O.A. //Неврол. журн.-1999.№ 2. - C. $52-55$.

12. Соловьева А.Д., Фииман Е.Я.//Журн. невропатол. и психиатр. - 1997. - № 11.-С.22-26.

13. Соловьева А.Д., Фишман Е.Я. //Журн. невропатол. и психиатр.-1999. - № 5.-С. 20-24

14. Сосюкало О.Д., Ермолина Л.А., Волошин В.М. и др. Депрессия в детском и подростковом возрасте (клинико-эпидемиологический аспект) //Материалы научно-практ. конф. по неврол. и психиатр. детского и подросткового возраста.Калуга, 1988.-С.125-127.

15. Талиикая О.Е., //варков С.Б. //Журн. невропатол. и психиатр. -1999.-№ 2.-С.11-14.

16. Филатова T.С. Метаболизм катехоламинов при психогенных депрессиях у психопатических личностей: Автореф. дис. ... канд. биол. наук.M., 1996.

17. Souetre E., Salvati E. //Neurophys. clin. - 1987.Vol. 17.-P.359-376.

18. Garraida $E$. //Medicine international.-1983.Vol. 34.-P.1594-1598.

\title{
M.B. Белоусова
}

\section{ПСИХОГЕННЫЕ РАССТРОЙСТВА У ДЕТЕЙ, ПЕРЕНЕСШИХ ПЕРИНАТАЛЬНОЕ ПОРАЖЕНИЕ ЦНС: ЭТИОЛОГИЯ, ПАТОГЕНЕЗ, КЛИНИКА, КОРРЕКЦИЯ}

\author{
Казанская государственная медицинская академия
}

\footnotetext{
Р е фе ра т. Изучены особенности возникновения психогенных расстройств у детей и дана оценка эффективности проводимой психотерапии. В кАинике психогенных расстройств превалировали тревожнодепрессивный, церебрастенический и фобический синдромы. У $112(67,9 \%)$ детей отмечался повышенный уровень тревожности. У $124(75,2 \%)$ детей обнаружена низкая физиологнческая сопротивляемость стрессу. Эффективным в коррекции психогенных расстройств оказалось использование комбинированной психотерапин. Результаты анализа психотравмируюших воздействий позволяют рекомендовать использование адаптированных дия данного возраста психотерапевтических методик в комплексном печении психогенных расстройств.
}

\section{M.B.Eeroycoва}

ЦНС ПЕРИНАТААЬ ЗАРАРААНУ КИЧЕРГОН БА АААРДА ПСИХОГЕН ТАЙПЫ ЭТИОАОГИЯ, ПАТОГЕНЕЗ, КАИНИКА, КОРРЕКЦИЯ

\footnotetext{
Әлеге тикшерену балалардаты психоген тайпымышмарнын килеп чыгыш үзенчәлекләрен өйрәнү һәм үткәрелә торган психотерапиянен нәтижәлелеген билгеләу максатыннан чыгып алып барымды. Психоген көйсезлекләр кАиникасында тынычсыздык, төшенкелек $(59,0 \%)$, цереброастеник $(61,5 \%)$ hәм курку $(8,6 \%)$ синдромнары өстенлек алды. 34\% балаларда тынычсызАық дәрәжәсенен югары булуы бнлгеләнде. $87 \%$ балаларда стрессларга физиологик каршы тору нәтиж-
} 
әсенең тубән булуы ачыкланды. Психоген бозылулар ны психотерапия белән дәвалау яхшы нәтижәләргә китеруе бимгеләнде. Психикага жимергеч тәэсирләрне анализлау олеге яшьтәге балаларга яраштырган психотерапевтик методикалары психоген бозылуларны комплекслы дәвалауга тәкъдим итәргә мөмкинмек бирә.

\section{M.V. Belousova}

PSYCHOGENIC DISORDERS IN CHILDREN WITH PERINATAL INJURY OF CNS: ETHIOLOGY, PATHOGENESIS, CLINICAL PICTURE, CORRECTION

Peculiarities of occurence of psychogenic disorders in children are explored, and efficiency of psychotherapy is estimated. In clinical picture of psychogenic disorders anxiety-depressive $(59,0 \%)$, cerebroasthenic $(61,5 \%)$ and phobic $(8,6 \%)$ syndromes prevailed. In $34 \%$ of children increased level of anxiety was noted. In $87 \%$ of children low physiologic stress resistance was found. Use of psychotherapy in correction of psychogenic disorders was found to be effective. The performed analysis of psychotraumatic effects makes it possible to recommend use of psychotherapeutic procedures adapted for the given age in combined therapy of psychogenic disorders.

A ктуальность и важность изучения психогенных расстройств у детей обусловлены значительной распространенностью этой патологии в современных условиях $[1,11,12,13]$. В настоянее время регистрируется огчетливое повышение удельного веса психогенных расстройств в структу ре заболеваемости детей и подростков $[5,6]$. По последним данным ВО3, четкая связь с воздействием психотравмирующих факторов прослеживается в $45 \%$ случаев всех психических расстройств в детском возрасте. Многие исследователи отмечают, что рост пограничных нервно-психических расстройств и пониженная стрессоустойчивость детей, приводяшая К развитию психогений, связаны с перенесенным в детстве органическим поражением головного мозга, в том числе перинатального генеза $[4,8,91$. По литературным данным, в настоящее время признаки резидуально-органического поражения головного мозга перинатального генеза выявляются у 20-90\% детей $[2,3,7,10]$. Широкая распространенность органического поражения ЦНС перинатального генеза, возможность формирования психогенных расстройств и нервно-психической патологии на данной органической базе побуждают искать новые диагностические, клинические и коррекционные подходы для решения возникающих проблем на раннем этапе.

Щелью настоящей работы было изучение особенностей возникновения психогенных расстройств у детей и подростков, их клинических проявлений, а также эффективности психотерапевтической коррекции.
Были исследованы дети и подростки, находившиеся на стационарном лечении или обследовании в психоневрологическом отделении ДГБ № 8 и в детском отделении РПБ МЗ РТ, а также обратившиеся к психиатру или к психоневрологу амбулаторно по поводу нарушений поведения, трудносгей в учебе и в общении со сверстниками. В исследовании приняли участие 165 детей и подростков обоего пола в возрасте от 6 до 15 лет. Были выделены две возрастные грулпы: младшая - среди детей от 6 до 11 лет (82 чел.) и старщая - среди детей от 12 до 15 лет (83 чел.). Контрольная группа состояла из 50 здоровых школьников. В качестве основного критерия для отбора детей и включения их в программу исследования мы использовали четко установленный, клинически и документально подтвержденный факт перинатального поражения ЦНС. Следует подчеркнуть, что дети с грубым органическим поражением головного мозга, проявляющимся выраженной очаговой неврологической симптоматикой и значительными нарушениями высших корковых функций, не входили в число обследуемых. Контингент обследованных был представлен детьми, у которых имели место последствия перинатального поражения ЦНС в форме минимальной мозговой дисфункции. Вторым необходимым условием для включения детей в программу исследования являлось наличие актуальной психотравмирующей ситуации, приводящей к развитию психогенных расстройств.

Использовали такие клинические методы, как клинико-анамнестический и клиникодинамический, проводили экспериментально-психологическое обследование. Уровень и характер тревожности изучали с помощью теста Филлипса. Анализировали количественные и качественные характеристики патологических факгоров, неблагоприятно воздействовавших в перинатальном периоде.

На момент осмотра подробное неврологическое обследование выявило признаки перенесенного перинатального поражения ЦНС у $138(83,6 \%)$ пациентов. Универсальные проявления пограничной нервно-психической патологин отмечались у всех детей. Клинически у них выявлялись тревожность, страх, раздражительность, эмоциональная лабильность, астения, снижение настроения, повышенная утомляемость, плохой сон, неспособность к конструктивному поведению. Связь наблюдаемой симптоматики с четко установленной психотравмирующей ситуацией и последующим развитием заболевания послужила критерием для диагностики психогенных рас- 
стройств. Для подтверждения данных, полученных клиническими методами, было проведено экспериментально-психологическое исследование. Применение психологического тестирования позволило не только подтвердить данные клинических наблюдений, но и выявить причины и симптомы психогенных расстройств в более широком объеме.

Изучая и анализируя медицинскую документацию, анамнестические данные со слов родителей, членов семьи, воспитателей, педагогов и самого ребенка, мы попытались выявить возможные психогенные факторы, действуюшие свыше 3 месяцев и обладаюшие высокой значимостью в глазах ребенка. На основании результатов исследования можно утверждать, что в большинстве случаев отмечается сочетанное воздействие 46 психотравмируюших факторов. В качестве психогенных факторов чаще всего выступают внутрисемейные конфликты - ссоры родителей $(74,5 \%)$, их льянство $(71,5 \%)$, жестокое обращение с детьми $(26,7 \%)$, развод родителей $(30,3 \%)$ и создание разведенным супругом новой семьи $(18,8 \%)$, нарушение системы мать-дитя (24,8\%)). Нарушение взаимоотношений со сверстниками, трудности в общении, плохая адаптация в коллективе отмечались у $35,7 \%$ детей. Психоэмоциональные перегрузки в школе, напряженная учеба, посещение дополнительных занятий, изменение привычного стереотипа обшения в рамках школьных правил наблюдались в качестве психогенных факторов у $57 \%$ детей. Ошущение одиночества и бесцельности собственного существования было выявлено у $23,6 \%$ детей.

В клинике психогенных расстройств у детей превалировали такие синдромы, как депрессивный - у $133(80,6 \%)$, церебрастенический - у $150(90,9 \%)$, фобический - у $60(36,4 \%)$ и синдром поведенческих нарушений - у $37(22,4 \%)$. В контрольной группе у $15(30 \%)$ детей обнаружились незначительно выраженные проявления астении у $33(66,0 \%)$, депрессии - у $39(78,0 \%)$, тревожности - у $24(48,0 \%)$, поведенческие нарушения - у $11(22,0 \%)$.

Проанализированы качественные параметры астении, депрессии и тревожности. Изучению подлежали следующие факторы: чувство душевной опустошенности, расстройства настроения, обшие соматические симптомы, специфические соматические симптомы, психомоторные симптомы, суицидальные мысли, раздражительность, нерешительность. Для изучения уровня тревожности мы использовали тест Филлипса. С его помощью нам удалось проанализировать общее внутреннее состояние детей, которое определялось наличием "тревожных" факторов в семье и школе. Тест прост в выполнении и дает большой объем информации об эмоциональном состоянии ребенка в школе и о факторах тревожности, связанных с его обшественной, школьной жизнью и отношениями со сверстниками. Обнаружено, что обшая тревожность повышена у $112(67,9 \%)$ детей, фрустрация в достижении успеха - у $39(23,6 \%)$ детей из основной и у $9(18,0 \%)$ из контрольной группы, страх самовыражения - соответственно у 26 $(15,8 \%)$ и $13(26 \%)$, страх не соответствовать ожиданиям окружаюших - у $61(37,0 \%)$ и у $8(16,0 \%)$, страх перед ситуацией проверки знаний - у $48(29,1 \%)$ и у $6(12,0 \%)$, проблемы в отношениях с учителями - у $67(40,6 \%)$ и $11(22,0 \%)$.

Выявляемая в данном тесте высокая тревожность требует медицинской, педагогической и социальной коррекции. Параллельно с работой по устранению причин, вызвавших тревогу, у ребенка необходимо развивать способность справляться с повышенной тревогой самостоятельно. В процессе исследования у $124(75,2 \%)$ детей из основной и у $7(14,0 \%)$ из контрольной группы была обнаружена низкая физиологическая сопротивляемость стрессу - то есть выявлены особенности психофизиологической организации, снижаюшие приспособляемость ребенка к ситуациям психогенного характера и повышающие вероятность деструктивного реагирования на тревожный характер среды. Отмечено, что $131(79,4 \%)$ ребенок из основной и $13(26,0 \%)$ детей из контрольной группы плохо приспосабливаются к психотравмируюшим ситуациям, не способны адекватно реагировать на стрессовые факторы из повседневной жизни и нуждаются в психологической помоши и психотерапевтической коррекции.

Использованные нами проективные тесты цветовой тест Люшера и методика цветовых выборов, наряду с высокой информативностью, отличаются простотой в выполнении, доступностью и быстротой в интерпретации, что позволяет рекомендовать их для диагностики изучаемых расстройств даже в условиях амбулаторного приема. Результаты теста Люшера у $71(85,5 \%)$ подростка, у $64(78,0 \%)$ младших детей и у 6 (12,0\%) обследованных контрольной группы подтверждают наличие высокого уровня тревоги, напряжения, негативного отношения к жизни, неудовлетворенности эмоциональными контактами, бо- 
язни предпринимать что-то новое и свидетельствуют о потребности в покое, расслаблении, восстановлении сил, освобождении от воздействия стресса.

Клинико-физиологические особенности изучаемого контингента (эмоциональная неустойчивость, гиперактивность, высокий нейротропизм, низкий показатель экстравертированности, склонность к тревожности, неуверенность в себе, повышенная ранимость и чувствительность, низкие способности к адаптации в сочетании с ригидностью мышления, раздражительностью, быстрой истошаемостью и отвлекаемостью внимания, наличие неврологической симптоматики резидуально-органического генеза или актуальных психоневрологических проявлений невротического регистра, отягошенность неблагоприятными социально-психологическими факторами) побужлают к поиску адекватных и патогенетически обоснованных путей коррекции.

Обсуждая вопросы терапии психогенных расстройств, мы хотим огметить, что у изучаемого контингента вследствие клинических и возрастных особенностей представлялось сложным использовать психотерапевтические методики в их классическом варианте. В большинстве случаев создавалась "психотерапевтическая мозаика", и на каждом этапе нами подключалась наиболее приемлемая методика. В своей деятельности мы использовали элементы семейной, рациональной, поведенческой, групповой, игровой психотерапии, а также техники иносказания и метафор, арт-терапию, релаксационные упражнения и элементы аутогенной тренировки. На основном этапе - в стадии установления контакта -- "подстройку" осуцествляли ориентируясь на ведущую репрезентативную систему. В дальнейшем тактику психокоррекции разрабатывали индивидуально для каждого ребенка с учетом его личностных особенностей и ведущей репрезентативной системы. Проведение игровой (у 39, 1\%), групповой (у $54,8 \%$ ), семейной (у 72,1\%), рациональной (у 41,8\%) психотерапии позволило уменьшить частоту и выраженность клинических проявлений психогенных расстройств. Индивидуальные занятия (у 51,5\%) и групповые тренинги (у 48,9\%) способствовали отработке адекватных механизмов психологической зашиты и повышению устойчивости к психотравмируюшим воздействиям.

Таким образом, исследование позволило проанализировать количественные и качест- венные характеристики психогенных расстройств, возникаюших у детей, перенесших перинатальное поражение ЦНС. Выявляемые у большинства детей признаки переживаемого социального стресса в сочетании с низкой способностью к адаптации в психогенных ситуациях и массированным воздействием психотравмирующих факторов в условиях микросоциального окружения и в рамках социально-обшественной и школьной жизни свидетельствуют об актуальности обсуждаемой проблемы. Симптомы психогенных расстройств требуют ранней диагностики и полноченной коррекции. В качестве дифференциально-диагностических пособий мы предлагаем использовать перечисленные выше методики, которые достаточно эффективны. Проведенный анализ психотравмирующих воздействий позволяет рекомендовать использование адаптированных для данного возраста пгихокоррекционных методик с целью повышения эффективности лечения психогенных расстройств.

\section{ЛИТЕРАТУРА}

1. Александровский Ю.А. Пограничные психические расстройства.-М., 1997.

2. Буторина Н.Е., Буторин Г.Г. //Российск. психиатрич. журн. - 1999. - № 3.-С.13-22.

3. Буторина Н.Е., Колесниченко Т.Н. //Социальная и клиническая психиатрия. - 1996.-№ 1.-С.12-14.

4. Вострокнутов H.B. Дети и насилие /Основные понятия, механизмы психогенного травматизирования и социально-медицинские последствия развития: Материалы Всероссийск. научно-практ. конф. "Дети и насилие".-Екатеринбург, 1996.-С.62-74.

5. Гурьева B.A. Психогенные расстройства у детей и подростков.-М., 1996.

6. Дмитриева Т.Б. //Журн. невропатол. и психиатр. - 1997. - № 5.-С.4-6.

7. Ковалев В.В. Психиатрия детского возраста: Руководство для врачей.-Изд. 2-е, перераб. и доп.M., 1995

8. Морозов Г.В, Шумский Н.Г. Введение в клиническую психиатрию (пропедевтика в психиатрии).Н.Новгород, 1998.

9. Халецкая О.В., Троиин В.М. Минимальные дисфункции мозга в детском возрасте--Н.Новгород, 1995

10. Яременко Б.Р., Яременко А.Б., Горяинова Т.Б Минимальные дисфункции головного мозга у детей. -СПб., 1999

11. Ackerman P.T., Newton J.E., McPherson W.B. Jones J.G., Dykman R.A. //Child Abuse Negl.-1998.Vol. 22(8).-P.759-774.

12. Brown D.A., Salmon K., Pipe M.E., Rutter M., Craw S., Taylor B. //Child Abuse Negl.-1999.Vol. 23(3).-P.209-216.

13. Costello E.J., Angold A., March J., Fairbank J. //Psychol. Med.-1998.-Vol. 28(6).-P.1275-1288. 